\title{
Surface water productivity and paleoceanographic implications in the Cenozoic Arctic Ocean
}

\author{
Jochen Knies, ${ }^{1}$ Ute Mann, ${ }^{2}$ Brian N. Popp, ${ }^{3}$ Ruediger Stein, ${ }^{4}$ and Hans-Jürgen Brumsack ${ }^{5}$ \\ Received 16 March 2007; revised 7 September 2007; accepted 10 December 2007; published 13 March 2008.
}

[1] Study of bulk nitrogen contents and isotopic composition in Arctic Ocean sequences (Integrated Ocean Drilling Program Expedition 302) over the past 60 Ma revealed changes in the export flux and sources of sedimentary nitrogen. The paleoproductivity calculated from the fraction of organic nitrogen to total nitrogen is distinctly lower $\left(<20 \mathrm{~g} \mathrm{C} \mathrm{m}^{-2} \mathrm{a}^{-1}\right)$ during the ice-covered Neogene compared to the ice-free, warm, and biologically active early Paleogene $\left(\sim 50-100 \mathrm{~g} \mathrm{C} \mathrm{m}^{-2} \mathrm{a}^{-1}\right)$. Nitrogen isotope measurements from late Paleocene to early Eocene sediments provide evidence for a stepwise stratification and nutrient depletion in surface water masses. Cyanobacterial nitrogen fixation appeared to be the main source of nutrient $\mathrm{N}$ in the Arctic Ocean during the early-middle Eocene characterized by conditions of strong oxygen depletion, high nutrient $\mathrm{N}$ losses, and high organic carbon accumulation rates. We speculate that biological $\mathrm{CO}_{2}$ sequestration in the Arctic Ocean and enhanced organic carbon burial rates may have contributed to lower atmospheric $\mathrm{CO}_{2}$ subsequent to the early Eocene climate optimum.

Citation: Knies, J., U. Mann, B. N. Popp, R. Stein, and H.-J. Brumsack (2008), Surface water productivity and paleoceanographic implications in the Cenozoic Arctic Ocean, Paleoceanography, 23, PA1S16, doi:10.1029/2007PA001455.

\section{Introduction}

[2] The marine $\mathrm{N}$ cycle in the Arctic Ocean prior to the last glacial cycle is not well constrained [Stein and MacDonald, 2004]. The modern Arctic Ocean is a wellstratified, nutrient-poor basin characterized by low primary productivity and underlain by sediments with low organic matter contents [Aagaard et al., 1985; Schubert et al., 2001; Stein and MacDonald, 2004]. Variations in nitrogen isotope ratios $\left(\delta^{15} \mathrm{~N}\right)$ in surface sediments generally reflect differences in relative nutrient utilization [Schubert and Calvert, 2001]. However, variability in sedimentary $\delta^{15} \mathrm{~N}$ values during the last glacial/interglacial cycle may also have depended on changes in water column stratification. Lower $\delta^{15} \mathrm{~N}$ values during the Last Glacial Maximum compared to the Holocene probably resulted from extensive sea ice cover that promoted vigorous exchange between surface and deepwater nitrate sources [Schubert et al., 2001].

[3] Different conditions may have existed during the early Paleogene, when a warm ice-free, brackish and biologically productive environment prevailed in the Arctic Ocean [Backman et al., 2006; Moran et al., 2006]. Stein et al. [2006] concluded based on detailed organic-geochemical records constructed from Integrated Ocean Drilling Program

\footnotetext{
${ }^{1}$ Geological Survey of Norway, Trondheim, Norway.

${ }^{2}$ SINTEF Petroleum Research, Trondheim, Norway.

${ }^{3}$ Department of Geology and Geophysics, University of Hawai'i at Manoa, Honolulu, Hawaii, USA.

${ }^{4}$ Alfred Wegener Institute for Polar and Marine Research, Bremerhaven, Germany.

${ }^{5}$ Institute for Chemistry and Biology of the Marine Environment, Oldenburg University, Oldenburg, Germany.
}

Copyright 2008 by the American Geophysical Union. 0883-8305/08/2007PA001455\$12.00
(IODP) Expedition 302 (Arctic Ocean Coring Expedition $(\mathrm{ACEX}))$ core material that euxinic "Black Sea-type" conditions existed throughout the early to middle Eocene ( 53-44 Ma). Salinity stratification due to variable freshwater discharge in combination with high surface water productivity, enhanced export of phytoplanktonic organic carbon (OC) and/or the flux of laterally supplied terrestrial OC are most likely responsible for this development. A brackish environment for the middle Eocene "Azolla" freshwater event [Brinkhuis et al., 2006] is inferred from the consistent dominance of low-salinity dinoflagellate cysts and abundant chrysophyte cysts [Backman et al., 2006]. A similar setting inferred from the dominant abundance of low-salinity-tolerant dinoflagellate cysts is suggested for the Paleocene-Eocene transition [Sluijs et al., 2006; Pagani et al., 2006].

[4] The nutrient inventory in this environmental setting and its implications are unresolved. An important question is whether surface water productivity in the Paleogene Arctic Ocean was much higher compared to the Neogene as inferred from micropaleontological [Backman et al., 2006; Sluijs et al., 2006] and geochemical data [Stein et al., 2006], and if so, is the enhanced production related to increased fluvial nutrient supply as suggested by Pagani et al. [2006]. If the latter holds true, has marine productivity eventually increased in response to increased nutrient inventories and thus forced enhanced $\mathrm{CO}_{2}$ uptake that may have contributed to the atmospheric $\mathrm{CO}_{2}$ decline during the early Eocene [Pearson and Palmer, 2000; Lowenstein and Demicco, 2006]? In this paper, we use sedimentary nitrogen content and its isotopic signature along with bulk organic proxies (TOC, Rock Eval pyrolysis) and published micropaleontological data to investigate possible changes in paleoproductivity (PP), nutrient supply and the potential importance of 


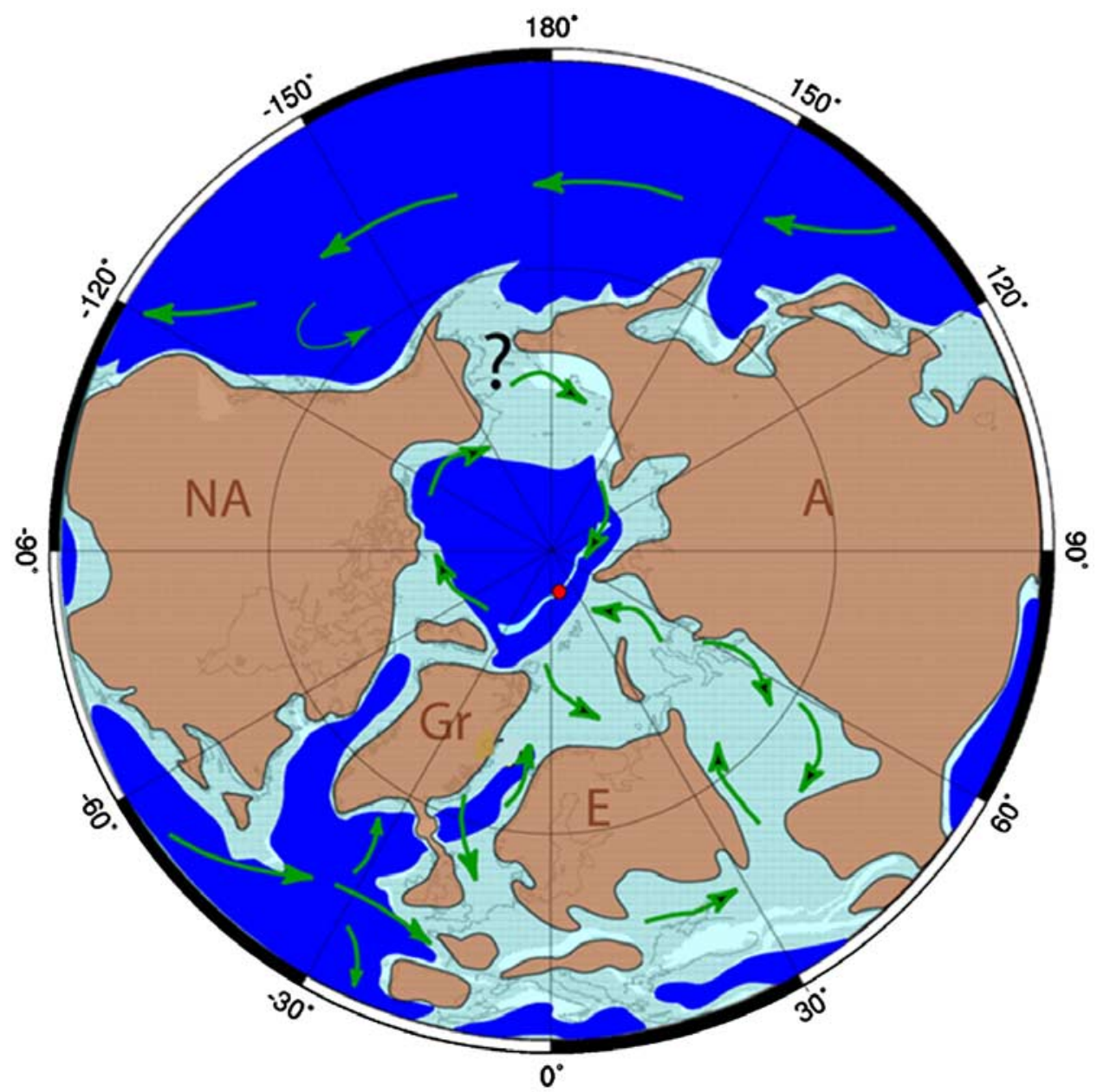

Figure 1. Paleogeographic map of the Northern Hemisphere around $50 \mathrm{Ma}$ [Backman et al., 2006 ]. Arctic Ocean Coring Expedition (ACEX) core location is displayed in red. Abbreviations are NA, North America; A, Asia; Gr, Greenland; and E, Europe. Arrows indicate surface water currents according to Backman et al. [2006, and references therein].

atmospheric nitrogen $\left(\mathrm{N}_{2}\right)$ fixation in the Cenozoic Arctic Ocean.

\section{Material and Methods}

[5] The sediment sequence (approximately $430 \mathrm{~m}$ ) recovered from the Lomonosov Ridge (Figure 1) during ACEX spans the Cenozoic and is divided into four major lithologic units (details given by Backman et al. [2006] and Moran et al. [2006]). According to the existing age model [Backman et al., 2006] the upper $\sim 200 \mathrm{mcd}$ (meter composite depth) extends from the early Miocene to the present with average sedimentation rates of $1-2 \mathrm{~cm} \mathrm{ka}^{-1}$, while the sequence from $\sim 200$ to $390 \mathrm{mcd}$ are late Paleocene to the early middle Eocene ( 44-56 Ma) in age with average sedimentation rates of $\sim 1$ to $3 \mathrm{~cm} / \mathrm{ka}$. Total nitrogen $\left(\mathrm{N}_{\text {tot }}\right)$ content and its organic $\left(\mathrm{N}_{\text {org }}\right)$ and inorganic $\left(\mathrm{N}_{\text {inorg }}\right)$ fractions have been analyzed for the upper three units $(0-400 \mathrm{mcd})$ consisting of siliciclastic, organic carbon-poor (unit 1), microlaminated, organic carbon-rich and biosilicious-rich (unit 2), and siliciclastic sediments (unit 3) with variable organic carbon content (Figure 2). The nitrogen isotopic compositions of the total $\left(\delta^{15} \mathrm{~N}_{\text {tot }}\right)$ and organic $\left(\delta^{15} \mathrm{~N}_{\mathrm{org}}\right)$ fractions are determined for the interval 295-303 mcd and 367-391 mcd representing the Paleocene/Eocene transition ( $\sim 56-53 \mathrm{Ma})$ and the "Azolla" freshwater event $(\sim 49-48 \mathrm{Ma})$, respectively. $\delta^{15} \mathrm{~N}_{\text {inorg }}$ values will be published elsewhere.

[6] Sediment samples (120) were analyzed for bulk nitrogen and its isotopic signature in Neogene and Paleogene sequences of IODP Leg 302 core material using the analytical procedures of Knies et al. [2007]. Briefly, total nitrogen $\left(\mathrm{N}_{\text {tot }}\right.$ in wt \%) content was determined on $20 \mathrm{mg}$ of freeze-dried and homogenized sediment sample. A second aliquot of equal mass was treated with $\mathrm{KOBr}-$ $\mathrm{KOH}$ solution to remove organic nitrogen $\left(\mathrm{N}_{\text {org }}\right)$ and the amount of inorganic nitrogen $\left(\mathrm{N}_{\text {inorg }}\right.$ in wt \%) bound as ammonium to the fine-grained sediments was determined [Silva and Bremner, 1966]. Total $\mathrm{N}\left(\mathrm{N}_{\text {tot }}\right)$, inorganic $\mathrm{N}$ $\left(\mathrm{N}_{\text {inorg }}\right)$, as well as the isotopic signature of total nitrogen $\left(\delta^{15} \mathrm{~N}_{\text {tot }}\right)$ and inorganic nitrogen $\left(\delta^{15} \mathrm{~N}_{\text {inorg }}\right)$ were determined by elemental analyzer isotope ratio mass spectrom- 


\section{Organic Nitrogen (\%)}

$\begin{array}{lllll}0 & 0.05 & 0.1 & 0.15 & 0.2\end{array}$

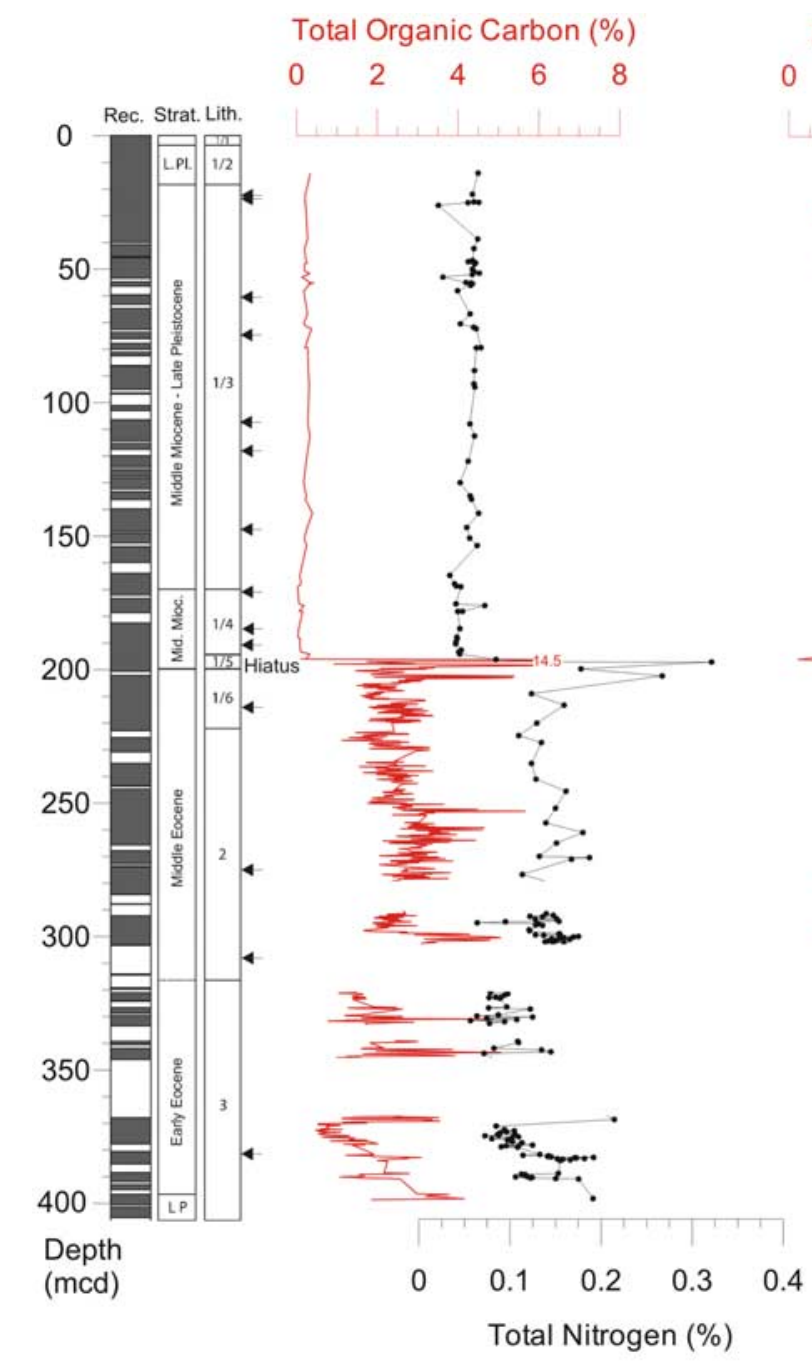

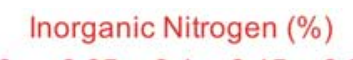

$\begin{array}{lllll}0 & 0.05 & 0.1 & 0.15 & 0.2\end{array}$
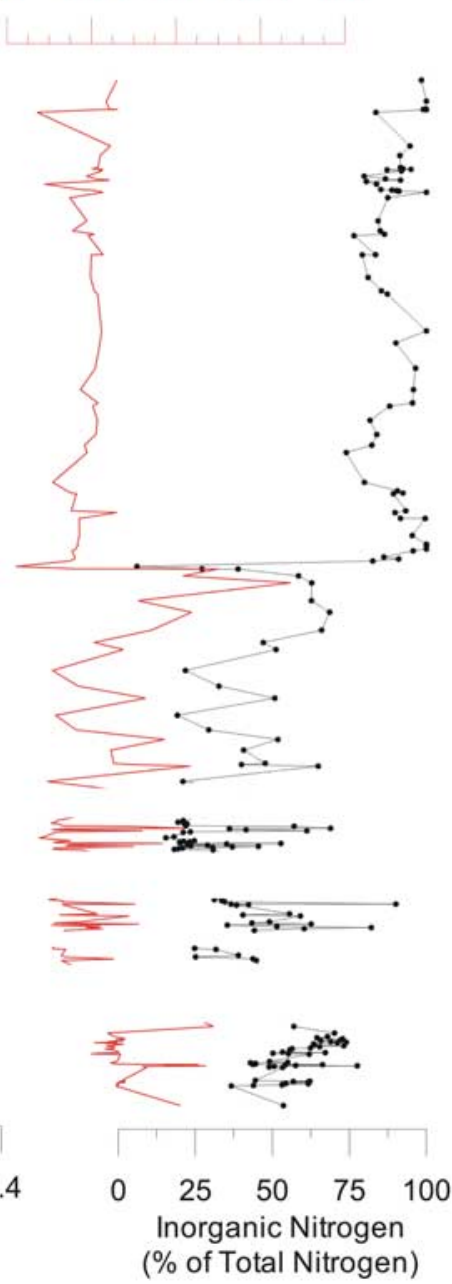

Figure 2. Down core variations of total organic carbon and total nitrogen as well as its various fractions (organic and inorganic) and their relative amounts on the total nitrogen content. Recovery, lithological units, and stratigraphic boundaries are displayed on the left-hand side [Backman et al., 2006]. etry (EA-IRMS) on an ANCA-GSL/20-20 system (Europa Scientific, Crewe, UK). Approximately $20 \%$ of the samples were analyzed in duplicate producing a mean standard deviation of $0.16 \%$. The results are in the per mil notation (\%o versus air). Reference material IA-R001 (wheat flour; $\delta^{15} \mathrm{~N}$ value $\left.=2.55 \%, 1.88 \% \mathrm{~N}(\mathrm{w} / \mathrm{w})\right)$ was obtained from Iso-Analytical Ltd. and analyzed repeatedly throughout sample analysis to check the accuracy of the measurements. The precision for treated and untreated samples was better than $\pm 0.2 \%$ o $(\mathrm{n}=120)$.

[7] $\mathrm{N}_{\text {org }}$ content and $\delta^{15} \mathrm{~N}_{\text {org }}$ values were calculated from the measured amounts of $\mathrm{N}_{\text {tot }}$ and $\mathrm{N}_{\text {inorg }}$ and isotopic values $\delta^{15} \mathrm{~N}_{\text {tot }}$ and $\delta^{15} \mathrm{~N}_{\text {inorg }}$ using isotope mass balance [Schubert and Calvert, 2001]. The possible influence of exchangeable nitrogen that is bound to clay mineral surfaces was not considered in this study. However, earlier studies [Müller, 1977; Freudenthal et al., 2001; Knies et al., 2007] in various settings have shown that the exchangeable nitrogen fraction represents a minor proportion, showing that exchangeable nitrogen is below 5 and $1 \%$ of the total nitrogen, respectively.

[8] The phosphorus content was determined on freeze dried and homogenized sediments, mixed with $3600 \mathrm{mg}$ of a mixture of dilithiumtetraborate/lithiummetaborate $\left(50 \% \quad \mathrm{Li}_{2} \mathrm{~B}_{4} \mathrm{O}_{7} / 50 \% \quad \mathrm{LiBO}_{2}\right)$, preoxidized at $500^{\circ} \mathrm{C}$ with $\mathrm{NH}_{4} \mathrm{NO}_{3}$ (p.a.), and fused to glass beads. All samples were analyzed for the major elements, including $\mathrm{Al}$ and $\mathrm{P}$ by XRF using a Philips PW 2400 X-ray spectrometer. Analytical precision and accuracy were better than $5 \%$ for all elements, as checked by international and several in-house reference materials.

\section{Results and Discussion}

\subsection{Organic Matter Sources Inferred From Various Nitrogenous Fractions}

[9] The Cenozoic sediments in the Arctic Ocean are characterized by two distinctly different $\mathrm{N}_{\text {tot }}$ contents. 
Neogene sediments ( 0 to $\sim 200 \mathrm{mcd}$ ) are almost devoid of nitrogen $(0.02-0.06 \%$, Figure 2). Below the hiatus separating lithological subunits $1 / 5$ and $1 / 6$, high-amplitude variations in $\mathrm{N}_{\text {tot }}$ between 0.05 and $0.2 \%$ occur (Figure 2). $\mathrm{N}_{\text {tot }}$ contents are highest $(0.3 \%)$ in subunit $1 / 5$ sediments. Unfortunately the stratigraphic age of subunit $1 / 5$ is not well constrained [Backman et al., 2006]; therefore it is not discussed further. Consistently high $\mathrm{N}_{\text {tot }}$ (mean $0.14 \%$ ) occur in biosilicious oozes of unit 2 while short-term fluctuations mark the late Paleocene-early Eocene transition (unit 3) (Figure 2). Various fractions of $\mathrm{N}_{\text {tot }}$ can represent different sources (aquatic versus terrigenous) of $\mathrm{OM}$ and may be quantitatively separated (Figure 2). Recent studies from the marginal Arctic Ocean indicated the potential of using relative amounts of $\mathrm{N}_{\text {inorg }}$ and $\mathrm{N}_{\text {org }}$ to track inputs of terrigenous (TOM) and aquatic/marine organic matter (MOM) to marine sediments [Winkelman and Knies, 2005; Knies et al., 2007]. Applying this approach to the ACEX records, we identify a prominent pattern in organic matter (OM) supply for Neogene sediments. Percent $\mathrm{N}_{\text {inorg }}$ (defined as $\mathrm{N}_{\text {inorg }} / \mathrm{N}_{\text {tot }}$ percent, Figure 2) indicates dominant TOM input to Arctic Ocean sediments consistent with the well-know depositional environment during the last glacial/interglacial cycle [e.g., Schubert and Stein, 1996; Stein and MacDonald, 2004]. The dominance of inorganic nitrogen $\left(>80 \% \mathrm{~N}_{\text {inorg }}\right)$ in generally nitrogen-poor sediments strongly suggests low-productive, presumably annual sea ice-covered surface waters throughout the Neogene and is consistent with the presence of ice-rafted debris [Moran et al., 2006] indicating glacial erosion and fluvial (meltwater) outwash of the adjacent hinterland. This is also supported by persistently elevated maximum pyrolytic hydrocarbon genera-

$$
\begin{array}{cc}
\text { organic carbon flux } & \text { dilution } \\
\downarrow & \downarrow \\
M O C=\left(\frac{0.409 P P^{1.41 *} z^{-0.63}}{10}\right) *\left(\frac{100}{D B D * L S R}\right)
\end{array}
$$

tion temperatures $\left(\mathrm{T}_{\max }>450^{\circ} \mathrm{C}\right)$ determined by Rock Eval indicating allochthonous, reworked, highly mature $\mathrm{OM}$ in Neogene sediment sequences (Figure 2) [Backman et al., 2006].

[10] Our records of various nitrogenous fractions indicate that the depositional environment during the Paleogene "greenhouse" was quite different from the Neogene "icehouse" conditions [Moran et al., 2006]. Percent $\mathrm{N}_{\text {inorg }}$ content is distinctly lower in Paleogene sequences compared to the Neogene (Figure 2). Particularly, the biosilicious oozes of unit 2 are characterized by constantly high percent $\mathrm{N}_{\text {org }}$ values $(>40 \%)$ suggesting the predominance of MOM input that is consistent with the interpretations of bulk organic data and kerogen microscopy [Stein et al., 2006]. A trend to lower percent $\mathrm{N}_{\text {org }}$ values occurs near the Paleocene/Eocene boundary (Figure 2). Particularly, prior and subsequent to the Paleocene-Eocene thermal maximum (PETM), significantly higher amounts of percent $\mathrm{N}_{\text {inorg }}$ indicate pulses of enhanced TOM input most likely resulting from variability in sea level (Figure 2) [Sluijs et al., 2006; Stein et al., 2006].

\subsection{Paleoproductivity in the Arctic Ocean Over the Past $60 \mathrm{Ma}$}

[11] To obtain quantitative information on paleoproductivity changes in the Arctic Ocean over the past $60 \mathrm{Ma}$, we estimated paleoproductivity (PP) in surface waters from marine organic carbon data of the underlying sediments [Knies and Mann, 2002, and references therein]. Applying marine organic carbon as a paleoproductivity proxy has been extensively discussed for Cenozoic sediments underlying oxic and anoxic bottom waters [e.g., Müller and Suess, 1979; Brumsack, 1980; Stein, 1986, 1991; Sarnthein et al., 1987, Bralower and Thierstein, 1984]. The amount of marine organic carbon was derived from percent $\mathrm{N}_{\text {org }}$ data which is reasonable to assume based on the correlation of percent $\mathrm{N}_{\text {org }}$ with Rock Eval hydrogen index (HI) values and kerogen microscopy (Figure 3, see discussion above); the latter two are well-established tracers for separating terrigenous (higher plant) and aquatic (fresh water and/or marine) OM [e.g., Stein et al., 2006]. High percent $\mathrm{N}_{\text {org }}$ values generally coincide with $\mathrm{HI}$ values $>250 \mathrm{mg} \mathrm{HC} / \mathrm{g}$ TOC reflecting a gradual increase in hydrogen-rich $\mathrm{MOM}$ supply (Figure 3).

[12] Primary productivity was estimated using the method of Knies and Mann [2002, and references therein]. Their equation includes the three main processes relating marine sedimentary organic carbon content to primary productivity in surface water: (1) decomposition of primary produced $\mathrm{OM}$ in the water column, (2) decomposition in sediments (burial efficiency), and (3) dilution by inorganic sediment.

[13] These factors are numerically expressed as

burial efficiency

$$
\left(0.54-0.54 *\left(\frac{1}{0.037 * L S R^{1.5}+1}\right)\right)
$$

where MOC is marine organic carbon (in percent), $\mathrm{PP}$ is the primary productivity (in $\mathrm{g} \mathrm{C} \mathrm{m}^{-2} \mathrm{a}^{-1}$ ), $\mathrm{z}$ is the water depth at the time of deposition (in m), DBD is the dry bulk density of sediment (in $\mathrm{g} \mathrm{cm}^{-3}$ ), and LSR is the linear sedimentation rate (in $\mathrm{cm} \mathrm{ka}^{-1}$ ).

[14] Marine organic carbon contents were transformed into mass accumulation rates using the mean sedimentation rates and physical property data of Backman et al. [2006]. Paleowater depth estimates in the Arctic Ocean over the past $60 \mathrm{Ma}$ were derived from Moore and Leg 302 Expedition Scientists [2006]. Solving equation [1] for PP allows estimation of primary paleoproductivity of the overlying surface water from sediment data:

$$
P P=\left(\frac{M O C^{*} 0.378^{*} D B D^{*} L S R^{*} z^{0.63}}{\left(1-\left(\frac{1}{0.037^{*} L S R^{1.5}+1}\right)\right)}\right)^{0.71}
$$




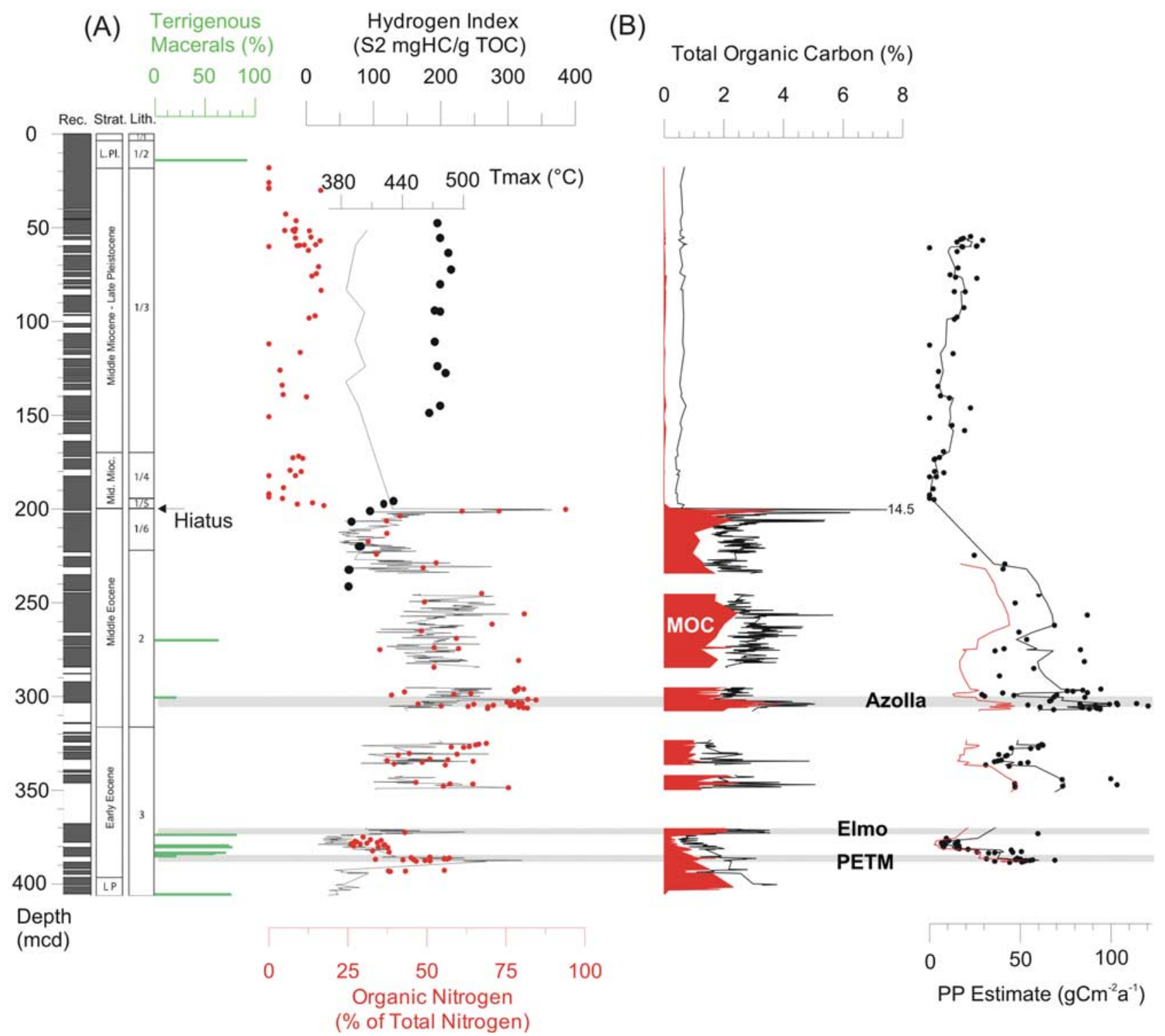

Figure 3. (a) Data compilation of kerogen microscopy (terrigenous macerals in percent), temperature at maximum hydrocarbon generation (Tmax in ${ }^{\circ} \mathrm{C}$ ), and Rock Eval hydrogen index [Backman et al., 2006; Stein et al., 2006] versus relative amounts of organic nitrogen on the total nitrogen fraction (percent $\mathrm{N}_{\mathrm{org}}$ ).

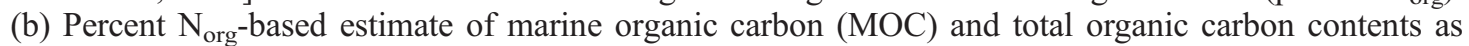
well as calculated paleoproductivity using the formula of Knies and Mann [2002, and references therein]. Black smoothed curve shows moving average PP data; red smoothed curve shows moving average PP data assuming increased preservation under anoxic conditions, i.e., applying a preservation factor of 1 according to Bralower and Thierstein [1984]. Recovery, lithological units, and stratigraphic boundaries are displayed on the left-hand side.

[15] Estimated PP for Neogene sediments of Leg 302 is low, generally less than $20 \mathrm{~g} \mathrm{C} \mathrm{m}^{-2} \mathrm{a}^{-1}$ (Figure 3). These values may reflect the low-productive, presumably annual sea ice-covered environment and are comparable with present-day PP values in the Central Arctic [e.g., Wheeler et al., 1996; Sakshaug, 2004]. In contrast, estimated PP values during the early Paleogene in Leg 302 sediments are remarkably high, but display strong fluctuations (Figure 3). Paleogene PP increases threefold relative to the Neogene and generally range between 40 and $80 \mathrm{~g} \mathrm{C} \mathrm{m}^{-2} \mathrm{a}^{-1}$, agreeing very well with calculated PP value of $50-75 \mathrm{~g} \mathrm{C} \mathrm{m}^{-2} \mathrm{a}^{-1}$ published by Stein [2007]. Within the "Azolla" freshwater event (AFE) PP reaches maximum values of $120 \mathrm{~g} \mathrm{C}$ $\mathrm{m}^{-2} \mathrm{a}^{-1}$ (Figure 3). Stein et al. [2006] suggested that a euxinic environment and increased $\mathrm{OM}$ preservation existed during deposition of unit 2 and partly unit 3, therefore calculated PP values may be slightly lower (see red curve in Figure 3) since euxinic conditions in sediments potentially would have preferentially preserved OM. These distinctly higher Paleogene PP estimates compared to the Neogene indicate a change in environmental conditions suggesting ice-free conditions allowing year-round surface water pro- 


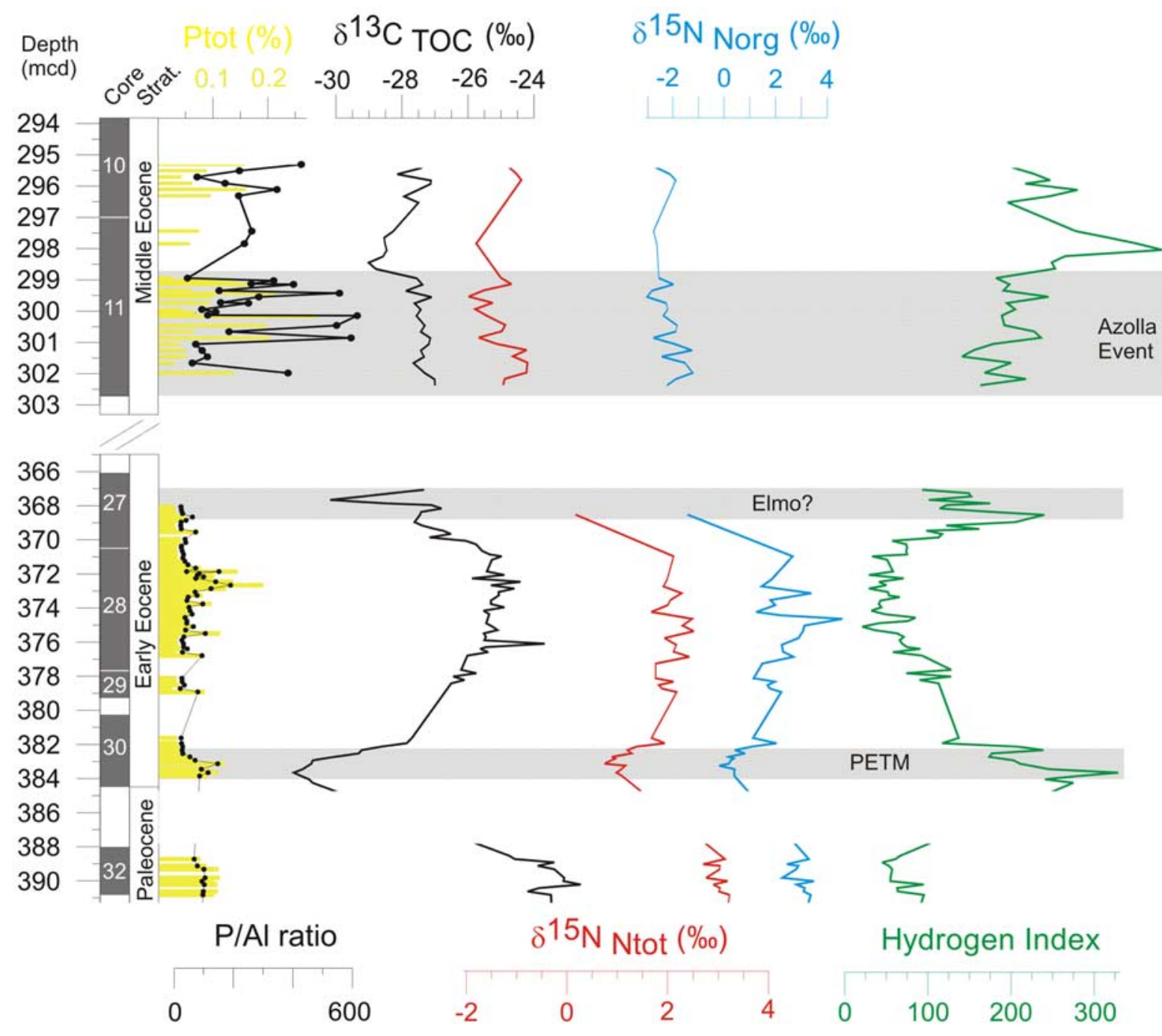

Figure 4. Down core variations of total phosphorus ( $\mathrm{P}$ in percent), phosphorus/aluminium ( $\mathrm{P} / \mathrm{Al}$ ) ratio, $\delta^{13} \mathrm{C}$ of organic carbon, $\delta^{15} \mathrm{~N}$ of total and organic nitrogen, and Rock Eval hydrogen index during course of the (top) "Azolla" freshwater event and (bottom) Paleocene-Eocene thermal maximum (PETM). Core recovery and stratigraphy are displayed.

ductivity. Surprisingly, PP estimates remains consistently high despite evidence for ice in the Arctic Ocean since $\sim 45 \mathrm{Ma}$ [Moran et al., 2006] indicating that seasonal (winter) sea-ice formation did not significantly effect annual primary production estimates. Relative to PP in modern environments estimated Paleogene PP is characteristic of enclosed and/or silled oceanic basins such as the Baltic Sea or Black Sea [Romankevich, 1984; Berger et al., 1989; Stein, 1991; Antoine et al., 1996] supporting the reconstruction of "Black Sea-type" conditions in the Paleogene Arctic Ocean [Stein et al., 2006]. For developing these "Black Sea-type" conditions, Sluijs et al. [2006] and later Stein et al. [2006] suggested that in addition to decreased mixing, increased primary production due to enhanced fluvial runoff might have caused euxinic conditions. This is neither supported nor confirmed by our PP calculations because the onset of euxinia was probably not recorded [Sluijs et al., 2006]. Arthur and Dean [1998] showed for the Black Sea that the development of anoxia was probably triggered by a short-term $(2-3 \mathrm{ka})$ burst of primary production, while anoxic conditions persisted subsequently throughout the water column despite much lower primary production and decreased flux of OM. The latter is in agreement with our observations that only moderate PP values $\left(\leq 100 \mathrm{~g} \mathrm{C} \mathrm{m}^{-2} \mathrm{a}^{-1}\right)$ in highly stratified waters provided the necessary preconditions to sustain anoxic conditions throughout the early middle Eocene. We now focus on two prominent global climate events during the Paleogene, the PETM and the "Azolla" freshwater event, and discuss the coupling of moderate PP values in stratified waters using the nutrient inventory in the following section.

\subsection{Negative Nitrogen Isotope Excursions During Extreme Climate Events}

[16] The $\delta^{15} \mathrm{~N}$ record of the total $\left(\delta^{15} \mathrm{~N}_{\text {tot }}\right)$ and organic nitrogen $\left(\delta^{15} \mathrm{~N}_{\text {org }}\right)$ during the Paleocene-Eocene transition ranges from $\sim 3.0$ to $-2.0 \%$ and $\sim 4.0$ to $-3.0 \%$, respec- 
tively (Figure 4). The change to lighter values in the organic fraction is likely due to contributions of inorganic nitrogen to the $\mathrm{N}_{\text {tot }}$. Both records show a stepwise depletion in ${ }^{15} \mathrm{~N}$ as a function of time from higher $\delta^{15} \mathrm{~N}$ values at the Paleocence-Eocene boundary interrupted by short-term negative excursions during the PETM $(<0.5 \%$ ) and the "Elmo event" $(<0 \%$ o [Sluijs et al., 2006; Stein et al., 2006] to generally lower $\delta^{15} \mathrm{~N}$ values $(<-1 \%)$ during the middle Eocene "Azolla" freshwater event (Figure 4) [Brinkhuis et al. 2006].

[17] The negative nitrogen isotope values occur only in sediments that are generally enriched in organic carbon (units 3 and 2) implying a close relationship to changes in the fertility of surface waters and coincident changes in the nutrient cycling in the Paleogene Arctic Ocean. Alternatively, the stratigraphic $\delta^{15} \mathrm{~N}$ records indicate that diagenetic overprint during particle settling and/or post depositional isotope fractionation are significantly different between organic carbon-rich and carbon-poor sediment sequences. The latter issues are probably of less relevance because of the following reasoning: (1) Moderate to good preservation of sedimentary OM in productive and oxygen depleted settings result in little diagenetic effects on $\delta^{15} \mathrm{~N}$ values compared to sinking particles [e.g., Altabet et al., 1999a, 1999b]. Although only studied in modern settings, similar conclusions may be drawn from the "Black Sea-type," oxygen deficient conditions in the Paleogene Arctic Ocean. (2) Postdepositional isotope effects associated with changes in thermal maturity and admixture of terrestrial-derived inorganic nitrogen (i.e., ${ }^{14} \mathrm{NH}_{4}^{+}$uptake onto clays) [Rau et al., 1987] is excluded because Rock Eval Tmax values < $425^{\circ} \mathrm{C}$ indicate thermally immature OM [Stein, 2007] and $\mathrm{N}_{\text {inorg }}$ was removed prior to nitrogen isotopic analyses. The small offset (mean $0.9 \%$ ) between the $\delta^{15} \mathrm{~N}_{\text {tot }}$ and $\delta^{15} \mathrm{~N}_{\text {org }}$ confirms that there is little net influence of $\mathrm{NH}_{4}^{+}$generation and/or, vertical diffusion, and adsorption between lattices of clay minerals on the sedimentary $\delta^{15} \mathrm{~N}$ values.

[18] Thus, by excluding diagenetic alteration of $\delta^{15} \mathrm{~N}$ values, we suggest that the ACEX sediment record directly reflect the $\delta^{15} \mathrm{~N}$ values of past inputs from the water column. Generally, $\delta^{15} \mathrm{~N}$ values of MOM in open ocean sediments reflect the extent of nitrate utilization by phytoplankton and the $\delta^{15} \mathrm{~N}$ of subsurface nitrate [e.g., Altabet and Francois, 1994; Farrell et al., 1995]. However, in oxygen-deficient environments, denitrification can cause a loss of biologically available nitrogen to the atmosphere (as $\mathrm{N}_{2} \mathrm{O}$ and $\mathrm{N}_{2}$ ), which leads to ${ }^{15} \mathrm{~N}$ enrichment of the remaining substrate at the depth of oxygen consumption [Cline and Kaplan, 1975]. Indeed, euxinic conditions in the Arctic Ocean would likely have favored denitrification in the water column resulting in ${ }^{15} \mathrm{~N}$ enrichment in the $\mathrm{OM}$ in underlying sediments. However, this is not supported by the sedimentary isotope data. Encoding the isotopic signature of denitrification in the sediments requires upwelling of a ${ }^{15} \mathrm{~N}$-rich water mass into the photic zone. If on the contrary, $\mathrm{N}_{2}$ fixation were occurring in surface waters, the biological input of the biomass of diazotrophs ( $\sim 0$ to $-4 \%$ [e.g., Carpenter et al., 1997; Holl et al., 2007]) would lead to very significantly reduced values of $\delta^{15} \mathrm{~N}$ of particulate nitrogen. Indeed, sediment $\delta^{15} \mathrm{~N}$ values are constantly low
$(<0 \%$ ) during phases of high organic carbon flux and persistent oxygen deficiency, and approach values similar to the oceanic mean $\delta^{15} \mathrm{~N}_{-} \mathrm{NO}_{3}^{-}(4-5 \%$ ) [Sigman et al., 1999] only during short-term intervals prior and subsequent to the PETM when oxic conditions prevailed (Figure 4) [Stein et al., 2006]. Accordingly, atmospheric dinitrogen $\left(\mathrm{N}_{2}\right)$ fixation must be considered likely during periods of high OM supply, which was concomitant with denitrification in suboxic waters overlying anoxic water masses. Apart from oligotrophic oceanic regions where $\mathrm{N}_{2}$ fixation is a widely known phenomenon [e.g., Karl et al., 1997, and references therein], evidence for $\mathrm{N}_{2}$ fixation also exist from oxygen depleted, stratified modern and ancient (semienclosed) oceanic basins [Rau et al., 1987; Walsh, 1996; Capone et al., 1997; Brandes et al., 1998; Haug et al., 1998; Sachs and Repeta, 1999; Septhon et al., 2002; Kuypers et al., 2004; Sigman et al., 2005; Westberry and Siegel, 2005; Voss et al., 2005; Deutsch et al., 2007; Junium and Arthur, 2007; White et al., 2007].

[19] In the well-stratified and euxinic Arctic Ocean, upwelling of nitrate deficit waters generated in oxygen minima zones by denitrification and/or anammox bacteria [Cline and Kaplan, 1975; Kuypers et al., 2003] followed by Redfield-type nutrient drawdown should result in nitrate limitation in the photic zone and may have given $\mathrm{N}_{2}$-fixing organisms an ecological advantage. The excess of phosphate in these laminated, organic-rich sediments (Figure 4) in conjunction with precipitation of carbonate fluorapatite CFA (C. Vogt, personnel communication, 2007) from the Arctic Ocean directly supports this suggestion. Phosphogenesis and water column denitrification are closely coupled processes in oxygen-depleted environments [Codispoti, 1989; Ganeshram et al., 2002] resulting in a deficit of nitrate relative to phosphate in anoxic water masses. Occasional perhaps wintertime mixing would deliver to surface waters nutrient concentrations depleted in $\mathrm{N}$ relative to $\mathrm{P}$ (low N:P ratio), which would favor the growth of $\mathrm{N}_{2}$ fixers until P became depleted [Tyrrell, 1999; Deutsch et al., 2007]. Excretion of organic and inorganic $\mathrm{N}$ by diatrophs and remineralization of the biomass may have released a ${ }^{15} \mathrm{~N}$ depleted nitrogen source for algal growth in the photic zone. Another plausible explanation follows the reasoning for sapropel formation in the Mediterranean Sea [Sachs and Repeta, 1999], where high abundances of specific diatom assemblages supporting nitrogen-fixing bacterial symbionts existed in stratified, nutrient-impoverished waters and contributed extensively to the organic-rich nature of the sapropels [Kemp et al., 1999]. However, it is currently unclear whether any members of the diatom assemblage in the Arctic sediments were able to live in symbiosis with $\mathrm{N}_{2}$ fixers (K. Takahashi, personnel communication, 2006). However, Backman et al. [2006] reported the regular occurrence of the diatom Hemiaulus spp. in lithological unit 2. Laboratory and field studies have demonstrated that Hemiaulus spp. has specific adaptations for stratified waters including symbiosis with $\mathrm{N}_{2}$-fxing bacteria [Villareal, 1991; Carpenter et al., 1999] and that these diatoms contributed to the formation of organic-rich Mediterranean sapropels [Kemp et al., 1999], a hypothesis that might be tested using nitrogen isotopic analyses of diatom matrix organic matter 


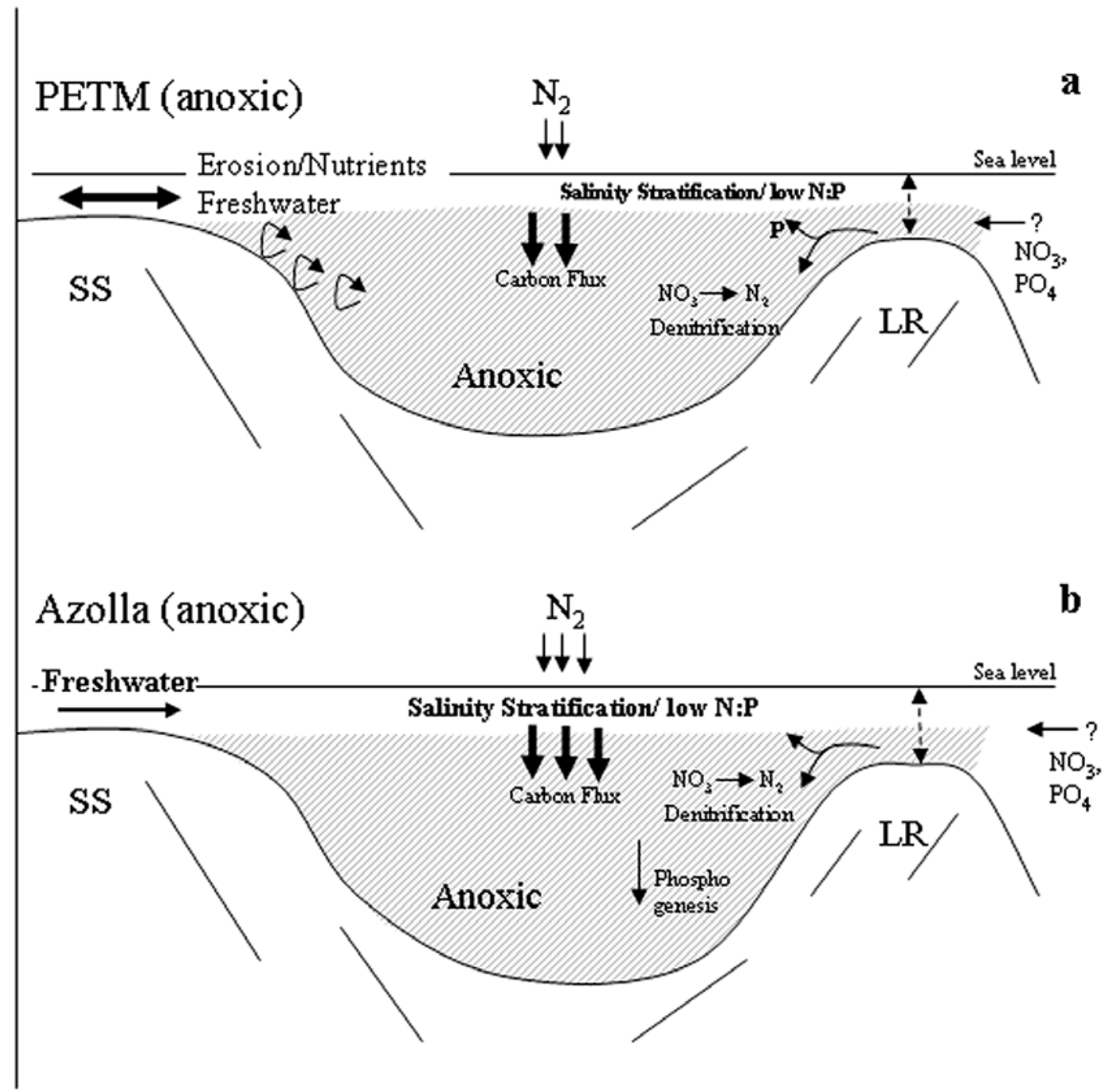

Figure 5. Paleoceanographic model showing suggested processes in the eastern Arctic Ocean during the (a) PETM (anoxic, photic zone euxinia) and (b) middle Eocene (anoxic).

[Robinson et al., 2005]. Moreover, Azolla aquatic fern is associated with nitrogen-fixing symbionts [Peters and Meeks, 1989]. Regardless of the dominant process, other sources of nitrogen such as rivers, rain, or exchange with open ocean water may be unlikely because the isotopic value of the nitrogen inventory, assuming modern conditions, would be ${ }^{15} \mathrm{~N}$ enriched. Hence, we conclude that the unusually low $\delta^{15} \mathrm{~N}$ values are best interpreted as reflecting the growth of $\mathrm{N}_{2}$-fixing organisms in nutrient-impoverished, well stratified surface water masses during the early middle Eocene suggesting that theses organisms played a major role in the development of early Paleogene organic-rich deposits in the Arctic Ocean.

\subsection{Paleoceanographic Implications}

[20] The Paleocene-Eocene thermal maximum (PETM) represents a prominent and abrupt climate anomaly in Earth history with sea surface temperatures increasing by as much as $5^{\circ} \mathrm{C}$ in the tropics and the Arctic Ocean [e.g.,
Röhl et al., 2000; Thomas et al., 1999, 2002; Zachos et al., 2003, 2006; Tripati and Elderfield, 2004; Sluijs et al., 2006]. Evidence suggests that a rise in greenhouse carbon levels $\left(\mathrm{CH}_{4}\right.$ and/or $\left.\mathrm{CO}_{2}\right)$ was responsible for this global warming [e.g., Dickens et al., 1995, 1997; Bowen et al., 2004; Svensen et al., 2004]. The PETM response in the Arctic Ocean was a drastic change in the depositional environment from apparently near coastal, oxic to anoxic conditions; the latter caused by increased sea surface temperatures and fluvial runoff accompanied by higher nutrient load that triggered primary production and thus oxygen deficiency [Pagani et al., 2006; Sluijs et al., 2006; Stein et al., 2006].

[21] However, our proxy records do not support this overall conclusion. Rather we suggest that the abrupt shift to more negative $\delta^{15} \mathrm{~N}$ values during the PETM (the lower bound of the PETM was probably not sampled because of recovery problems [Sluijs et al., 2006]) marks a change in the nitrogen inventory in the Arctic Ocean driven by a coupling of denitrification with $\mathrm{N}_{2}$ fixation (Figure 5a). We 


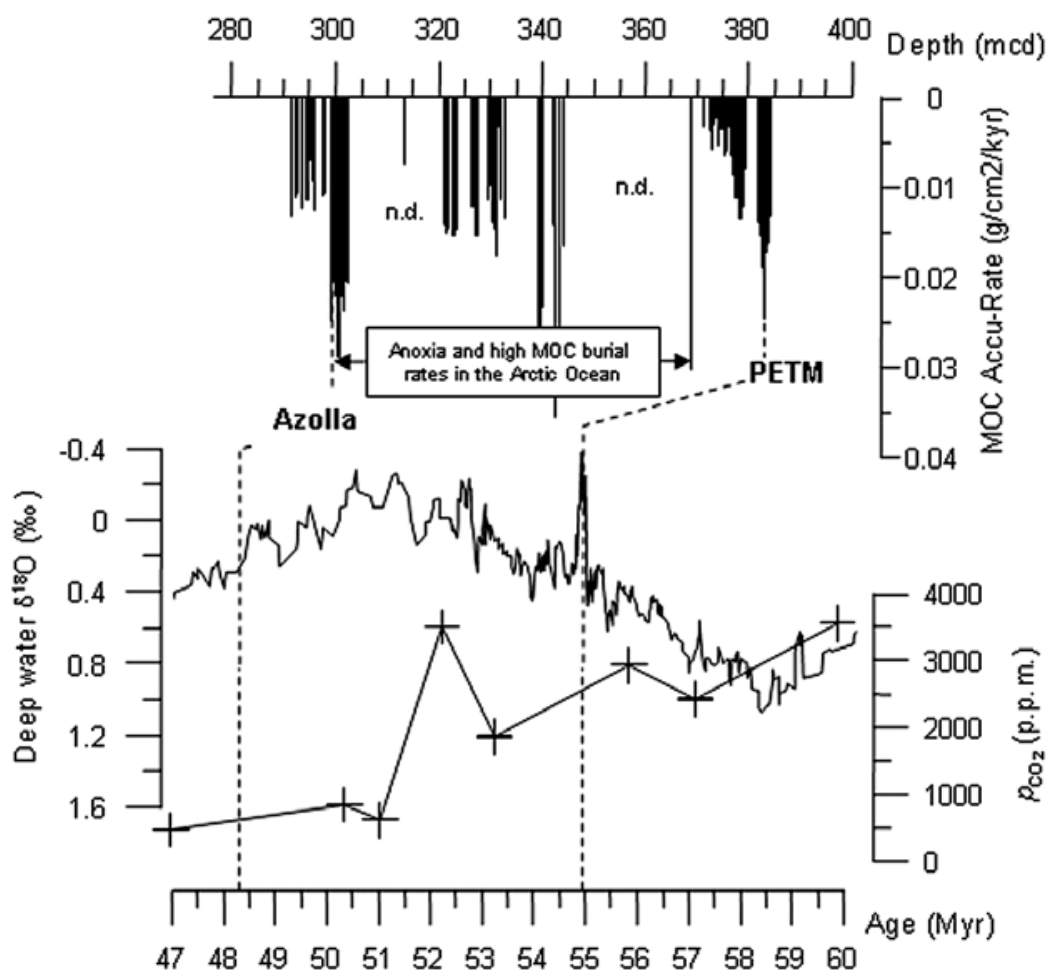

Figure 6. Compilation of carbon dioxide levels [Pearson and Palmer, 2000] and benthic foraminifer $\delta^{18} \mathrm{O}$ record [Zachos et al., 2001] during the early Cenozoic and the accumulation rates of marine organic carbon in the central Arctic Ocean. Dashed lines represent two biostratigraphic datums (55 and 48.3 Ma) in the ACEX record.

suggest that nitrogen supply to the photic zone from enhanced river runoff was insignificant compared to diazotrophy as the main nitrogen source. Nutrients imported through runoff to the Arctic Ocean would rapidly have been recycled and trapped in a nutricline-associated halocline. The expansion and intensification of the euxinic conditions during the PETM may have increased the conversion of nitrate to $\mathrm{N}_{2}$ via denitrification (Figure 5a). A deficit of nitrate relative to phosphate in the photic zone would allow $\mathrm{N}_{2}$-fixing organisms to compete effectively with or even outcompete other marine phytoplankton (during summer stratification) and lead to low $\delta^{15} \mathrm{~N}$ values in sinking material and sediments (during winter mixing and fallout) [cf. Rau et al., 1987; Kemp et al., 1999]. The signal may be amplified by the utilization of nitrogen derived from ${ }^{15} \mathrm{~N}$ depleted ammonium sourced from the underlying euxinic water column, as suggested for the photic zone euxinia during the Cretaceous OAE II [Junium and Arthur, 2007]; however, unless the significance of anaerobic ammonium oxidation by anammox bacteria [e.g., Kuypers et al., 2003] for the PETM is clarified this assumption remains rather speculative.

[22] Thus enhanced fluvial runoff and rapid sea level rise likely triggered the incursion of nutrient-rich waters during onset of the PETM providing the baseline for phytoplankton blooms and oxygen deficiency, but, contrary to previous inferences, did not supply appreciable quantities of nitrogen for enhanced phytoplankton production during the PETM.
Instead, $\mathrm{N}_{2}$-fixing organisms in a brackish, nutrientimpoverished photic zone provided the $\mathrm{N}$ source, directly through diazotrophy or indirectly through remineralization of their biomass, to sustain phytoplankton growth and thus higher organic carbon flux in the water column (Figure 5a). By the end of the PETM, the system recovered, surface water cooled and sea level dropped. $\mathrm{N}_{2}$-fixing organisms were then outcompeted as soon as denitrification and primary production ceased and riverine-derived TOM supply increased.

[23] Persistently low $\delta^{15} \mathrm{~N}$ values during the Azolla freshwater event ( $49 \mathrm{Ma}$ ) (Figure 4) [Brinkhuis et al., 2006] imply that the Arctic Ocean nitrogen inventory may have still been sustained by diazotrophy (Figure 5b). Large quantities of the fern Azolla indicate strong salinity stratification and episodic freshening of Arctic surface waters during a $0.8 \mathrm{Ma}$ interval [Brinkhuis et al., 2006]. Oxygen deficient conditions prevailed during this period [Stein et al., 2006], but surface water temperatures were much cooler during the Azolla event $\left(\sim 10^{\circ} \mathrm{C}\right)$ and TOM supply was rather low compared to the PETM (Figure 5a) [Brinkhuis et al., 2006; Stein et al., 2006]. Nonetheless, the low $\delta^{15} \mathrm{~N}$ values imply that $\mathrm{N}_{2}$-fixing organisms likely sustained the surface water productivity and thus may be the driving force for anoxia (Figure 5b). The former is supported by the fact that Azolla freshwater plant is typically associated with $\mathrm{N}_{2}$ fixing symbionts [Peters and Meeks, 1989].

[24] This model of denitrification- $\mathrm{N}_{2}$ fixation coupling has been linked to short-term global/regional climate per- 
turbations associated with anoxia such as the late Triassic [Sephton et al., 2002], Cretaceous oceanic anoxic events [Rau et al., 1987; Junium and Arthur, 2007], Pleistocene sapropel formation in the Mediterranean [Sachs and Repeta, 1999] and glacial/interglacial cycles in the Cariaco basin [Haug et al., 1998]. Recent observations for black shale formation during the middle Cretaceous (oceanic anoxic events (OAE) 1 and 2) [Kuypers et al., 2004] show that $\mathrm{N}_{2}$ fixation was likely the primary source of nutrient $\mathrm{N}$ for marine phytoplankton growth that contributed to high MOM accumulation under anoxic environmental conditions. Kuypers et al. [2004] further speculated whether the enhanced burial of organic carbon during OAEs may have acted as a biological pump, effectively reducing carbon dioxide $\left(\mathrm{CO}_{2}\right)$ concentrations of the middle Cretaceous "greenhouse" atmosphere. Interestingly, enhanced burial of organic carbon in the Arctic Ocean persisted from the PETM/Elmo to the Azolla freshwater event ( 55-49 Ma) (Figure 6), only interrupted shortly prior to and after the PETM. Pearson and Palmer [2000, and references therein] argued that the decline in atmospheric $\mathrm{CO}_{2}$ subsequent to the early Eocene climate optimum might have been caused by various factors including reduced $\mathrm{CO}_{2}$ outgassing and increased organic carbon burial. However, there is no direct evidence for sequestering of organic carbon into marine sediments in the Eocene. Bains et al. [2000] argued that high rates of organic carbon burial at the Paleocene-Eocene boundary might be indicative of a distinct cooling of the PETM greenhouse climate by additional sequestration of atmospheric $\mathrm{CO}_{2}$. However, this model has been argued against in various studies [e.g., Dickens et al., 2003, and references therein]. Yet it remains to be shown whether a 5-6 million year long period of enhanced "biological pump" was possibly fuelled by $\mathrm{N}_{2}$-fixing organisms in the eastern Arctic Ocean between Lomonosov Ridge and the Siberian mainland (Figure 1) (there is currently no evidence for euxinic conditions in the western Arctic Ocean (Amerasian Basin)) and has any implications on global $\mathrm{CO}_{2}$ sequestration and thus atmospheric $\mathrm{CO}_{2}$ concentration during the early Paleogene. At this stage, we can only speculate that an analogue to the "Miocene Monterey Formation hypothesis" [Vincent and Berger, 1985; Raymo, 1994] occurred in the Arctic during the early middle Eocene, namely, that high burial rates of marine organic carbon may have contributed to the global decline in atmospheric $\mathrm{CO}_{2}$ subsequent to the early Eocene climate optimum.

\section{Conclusions}

[25] Two prominent features in the nitrogen record of the Cenozoic Arctic Ocean reveals that (1) a very low productive surface water environment that is characterized by relatively high nutrient utilization prevailed throughout the Neogene and (2) a moderately productive surface environment existed during the early Paleogene that was apparently fuelled by $\mathrm{N}_{2}$-fixing organisms. Both periods were supposed to be well stratified, however, in contrast to the Neogene, a tight coupling of denitrification and $\mathrm{N}_{2}$ fixation in an anoxic environment with a well-established pycnocline might have caused nitrate depletion relative to phosphate that stimulated $\mathrm{N}_{2}$ fixation during the early Paleogene. We speculate that biological $\mathrm{CO}_{2}$ sequestration in the Arctic Ocean and enhanced organic carbon burial rates may have contributed to lower atmospheric $\mathrm{CO}_{2}$ subsequent to the early Eocene climate optimum.

[26] Acknowledgments. The samples were provided by the Integrated Ocean Drilling Program (IODP). We sincerely thank Appy Sluijs, Richard Zeebe, and Jim Zachos for comments on an earlier draft of the manuscript. This work was supported by the Norwegian Research Council (Leiv Eiriksson Mobility Program) and the German Science Foundation (DFG SPP IODP/ICDP). This is SOEST contribution 7331.

\section{References}

Aagaard, K., J. H. Swift, and E. C. Carmack (1985), Thermohaline circulation in the Arctic Mediterranean Sea, J. Geophys. Res., 90, 4833-4846.

Altabet, M. A., and R. Francois (1994), Sedimentary nitrogen isotopic ratio as a recorder for surface ocean nitrate utilization, Global Biogeochem. Cycles, 8, 103-116.

Altabet, M. A., D. W. Murray, and W. L. Prell (1999a), Climatically linked oscillations in Arabian Sea denitrification over the past 1 m.y.: Implications for the marine $\mathrm{N}$ cycle, Paleoceanography, 14, 732-743.

Altabet, M. A., C. Pilskaln, R. Thunnell, C. Pride, D. Sigman, F. Chavez, and R. Francois (1999b), The nitrogen isotope biogeochemistry of sinking particles from the margin of the eastern North Pacific, Deep Sea Res., Part I, 46, $655-679$.

Antoine, D., J.-M. André, and A. Morel (1996), Oceanic primary production: 2. Estimation at global scale from satellite (coastal zone color scanner) chlorophyll, Global Biogeochem. Cycles, 10, 57-69.

Arthur, M. A., and W. E. Dean (1998), Organic matter production and preservation and evolu- tion of anoxia in the Holocene Black Sea, Paleoceanography, 13, 395-411.

Backman, J., K. Moran, D. B. McInroy, L. A Mayer, and the Leg 302 Expedition Scientists (2006), Arctic Coring Expedition (ACEX), Proc. Integr. Ocean Drill. Program, 302.

Bains, S., R. D. Norris, R. M. Corfield, and K. L. Faul (2000), Termination of global warmth at the Palaeocene/Eocene boundary through productivity feedback, Nature, 407, 171-174

Berger, W. H., V. S. Smetacek, and G. Wefer (1989), Ocean productivity and paleoproductivity-An overview, in Productivity of the Ocean: Present and Past, edited by W. H. Berger, V. S. Smetacek, and G. Wefer, pp. 1-35, John Wiley, Hoboken, N. J.

Bowen, G. J., D. J. Beerling, P. L. Koch, J. C. Zachos, and T. Quattlebaum (2004), A humid climate state during the Paleocene/Eocene thermal maximum, Nature, 432, 495-499.

Bralower, T. J., and H. R. Thierstein (1984), Low productivity and slow deepwater circulation in Mid-Cretaceous oceans, Geology, 12, 614-618.

Brandes, J., A. Devol, T. Yoshinari, and D. Jayakumar (1998), Isotopic composition of nitrate in the central Arabian Sea and eastern tropical North Pacific: A tracer for mixing and nitrogen cycles, Limnol. Oceanogr., 43, 16801689

Brinkhuis, H., et al. (2006), Episodic fresh surface waters in the Eocene Arctic Ocean, Nature, 441, 606-609.

Brumsack, H. J. (1980), Geochemistry of Cretaceous black shales from the Atlantic Ocean (DSDP Legs 11, 14, 36, and 41), Chem. Geol. $31,1-25$.

Capone, D. G., J. P. Zehr, H. W. Paerl, B. Bergman, and E. J. Carpenter (1997), Trichodesmium, a globally significant marine cyanobacterium, Science, 276, 1221-1229.

Carpenter, E. J., H. R. Harvey, B. Fry, and D. G. Capone (1997), Biogeochemical tracers of the marine cyanobacterium Trichodesmium, Deep Sea Res., Part I, 44, 27-38.

Carpenter, E. J., J. P. Montoya, J. Burns, M. R. Mulholland, A. Subramaniam, and D. G Capone (1999), Extensive bloom of a $\mathrm{N}_{2}$ fixing diatom/cyanobacterial association in the tropical Atlantic Ocean, Mar. Ecol. Prog. Ser., 185, 273-283 
Cline, J. D., and I. R. Kaplan (1975), Isotopic fractionation of dissolved nitrate during denitrification in the eastern tropical North Pacific Ocean, Mar. Chem., 3, 271-299.

Codispoti, L. A. (1989), Phosphorus versus nitrogen limitation of new and export production, in Productivity of the Ocean: Present and Past, edited by W. Berger, V. S. Smetacek, and G. Wefer, pp. 377-394, John Wiley, Hoboken, N. J.

Deutsch, C., J. L. Sarmiento, D. M. Sigman, N. Gruber, and J. P. Dunne (2007), Spatial coupling of nitrogen inputs and losses in the ocean, Nature, 445, 163-167.

Dickens, G. R., J. R. O'Neil, D. K. Rea, and R. M. Owen (1995), Dissociation of oceanic methane hydrate as a cause of the carbon isotope excursion at the end of the Paleocene, Paleoceanography, 10, 965-971.

Dickens, G. R., M. M. Castillo, and J. C. G. Walker (1997), A blast of gas in the latest Paleocene: Simulating first-order effects of massive dissociation of oceanic methane hydrate, Geology, 25, 259-262.

Dickens, G. R., T. Fewless, E. Thomas, and T. J. Bralower (2003), Excess barite accumulation during the Paleocene-Eocene thermal maximum: Massive input of dissolved barium from seafloor gas hydrate reservoirs, in Causes and Consequences of Globally Warm Climates in the Early Palaeogene, edited by S. L. Wing et al., Spec. Pap. Geol. Soc. Am., 369, 11-23.

Farrell, J. W., T. F. Pedersen, S. E. Calvert, and B. Nielsen (1995), Glacial-interglacial changes in nutrient utilisation in the equatorial Pacific Ocean, Nature, 377, 514-517.

Freudenthal, T., T. Wagner, F. Wenzhöfer, M. Zabel, and G. Wefer (2001), Early diagenesis of organic matter from sediments of the eastern subtropical Atlantic: Evidence from stable nitrogen and carbon isotopes, Geochim. Cosmochim. Acta, 65, 1795-1808.

Ganeshram, R. S., T. F. Pedersen, S. E. Calvert, and R. Francois (2002), Reduced nitrogen fixation in the glacial ocean inferred from changes in marine nitrogen and phosphorus inventories, Nature, 415, 156-159.

Haug, G. H., T. F. Pedersen, D. M. Sigman, S. E. Calvert, B. Nielsen, and L. C. Peterson (1998), Glacial/Interglacial variations in production and nitrogen fixation in the Cariaco Basin during the last $580 \mathrm{kyr}$, Paleoceanography, 13, 427-432.

Holl, C. M., T. A. Villareal, C. D. Payne, T. D. Clayton, C. Hart, and J. P. Montoya (2007), Trichodesmium in the western Gulf of Mexico: ${ }^{15} \mathrm{~N}_{2}$-fixation and natural abundance stable isotope evidence, Limnol. Oceanogr., 52, $2249-$ 2259.

Junium, C. K., and M. A. Arthur (2007), Nitrogen cycling during the Cretaceous, Cenomanian-Turonian oceanic anoxic event II, Geochem. Geophys. Geosyst., 8, Q03002, doi:10.1029/2006GC001328.

Karl, D., R. Letelier, L. Tupas, J. Dore, and J. Christian (1997), The role of nitrogen fixation in biogeochemical cycling in the subtropical North Pacific Ocean, Nature, $388,533-538$

Kemp, A. E. S., R. B. Pearce, I. Koizumi, J. Pike, and S. J. Rance (1999), The role of mat-forming diatoms in the formation of Mediterranean sapropels, Nature, 398, 57-61.

Knies, J., and U. Mann (2002), Depositional environment and source rock potential of Miocene strata from the central Fram Strait: Introduction of a new computing tool for simulating organic facies variations, Mar.Pet. Geol., 19, 811-828.
Knies, J., S. Brookes, and C. J. Schubert (2007), Reassessing the nitrogen signal in continenta margin sediments: New insights from the high northern latitudes, Earth Planet. Sci. Lett. 253, 471-484

Kuypers, M. M. M., A. O. Sliekers, G. Larvik, M. Schmid, B. B. Jørgensen, J. G. Kuenen, J. S. Sinninghe Damsté, M. Strous, and M. S. M. Jetten (2003), Anaerobic ammonium oxidation by anammox bacteria in the Black Sea, Nature, 422, 608-611.

Kuypers, M. M. M., Y. van Breugel, S. Schouten, E. Erba, and J. S. Sinninghe Damsté (2004) $\mathrm{N}_{2}$-fixing cyanobacteria supplied nutrient $\mathrm{N}$ for Cretaceous oceanic anoxic events, Geology, $32,853-856$.

Lowenstein, T. K., and R. V. Demicco (2006), Elevated Eocene atmospheric $\mathrm{CO}_{2}$ and its subsequent decline, Science, 313, 1, 928 .

Moore, T. C., and the Leg 302 Expedition Scientists (2006), Sedimentation and subsidence history of the Lomonossov Ridge, in Arctic Coring Expedition (ACEX), Proc. Integr. Ocean Drill. Program, 302.

Moran, K., et al. (2006), The Cenozoic palaeoenvironment of the Arctic Ocean, Nature, 441, 601-605.

Müller, P. J. (1977), C/N ratios in Pacific deepsea sediments; effect of inorganic ammonium and organic nitrogen compounds sorbed by clays, Geochim. Cosmochim. Acta, 41, 765776.

Müller, P. J., and E. Suess (1979), Productivity, sedimentation rate, and sedimentary organic matter in the oceans-I. Organic carbon preservation, Deep Sea Res., Part A, 26, $1347-$ 1362

Pagani, M., N. Pedenchouk, M. Huber, A. Sluijs, S. Schouten, H. Brinkhuis, J. S. Sinninghe Damsté, and G. R. Dickens (2006), Arctic hydrology during global warming at the Palaeocene/Eocene thermal maximum, Nature, 442, 671-675.

Pearson, P. N., and M. R. Palmer (2000), Atmospheric carbon dioxide concentrations over the past 60 million years, Nature, 406, 695-699.

Peters, G. A., and J. C. Meeks (1989), The Azolla-Anabaena symbiosis: Basic biology, Annu. Rev. Plant Physiol. Plant Mol. Biol., 40, $193-210$.

Rau, G. H., M. A. Arthur, and W. E. Dean (1987), $15 \mathrm{~N} / 14 \mathrm{~N}$ variations in Cretaceous Atlantic sedimentary sequences: Implication for past changes in marine nitrogen biogeochemistry, Earth Planet. Sci. Lett., 82, 269 279.

Raymo, M. E. (1994), The Himalayas, organic carbon burial, and climate in the Miocene, Paleoceanography, 9, 399-404.

Robinson, R. S., D. M. Sigman, P. J. DiFiore, M. M. Rohde, T. A. Mashiotta, and D. W. Lea (2005), Diatom-bound ${ }^{15} \mathrm{~N} /{ }^{14} \mathrm{~N}$ : New support for enhanced nutrient consumption in the ice age subantarctic, Paleoceanography, 20, PA3003, doi:10.1029/2004PA001114

Röhl, U., T. J. Bralower, R. D. Norris, and G. Wefer (2000), New chronology for the late Paleocene thermal maximum and its environmental implications, Geology, 28, 927-930.

Romankevich, E. A. (1984), Geochemistry of Organic Matter in the Ocean, 334 pp., Springer, Berlin

Sachs, J. P., and D. J. Repeta (1999), Oligotrophy and nitrogen fixation during eastern Mediterranean sapropel events, Science, 286, $2485-2488$.

Sakshaug, E. (2004), Primary and secondary production in the Arctic Seas, in The Organic
Carbon Cycle in the Arctic Ocean, edited by R. Stein and R. W. Macdonald, pp. 57-82, Springer, Berlin.

Sarnthein, M., K. Winn, and R. Zahn (1987) Paleoproductivity of oceanic upwelling and the effect on atmospheric $\mathrm{CO}_{2}$ and climatic change during deglaciation times, in Abrupt Climatic Change, edited by A. L. Berger and L. Labeyrie, pp. 311-337, D. Reidel, Dordrecht, Netherlands.

Schubert, C. J., and S. E. Calvert (2001), Nitrogen and carbon isotopic composition of marine and terrestrial organic matter in Arctic Ocean sediments: Implications for nutrient utilization and organic matter composition, Deep Sea Res., Part I, 48, 789-810.

Schubert, C. J., and R. Stein (1996), Deposition of organic carbon in late Quaternary Arctic Ocean: Terrigenous supply vs. marine productivity, Org. Geochem., 24, 421-436.

Schubert, C. J., S. E. Calvert, and R. Stein (2001), Tracking nutrient and productivity variations over the last deglaciation in the Arctic Ocean, Paleoceanography, 16, 199-211.

Sephton, M. A., K. Amor, I. A. Franchi, P. B Wignall, R. Newton, and J.-P. Zonneveld (2002), Carbon and nitrogen isotope disturbances and an end-Norian (Late Triassic) extinction event, Geology, 30, 1119-1122.

Sigman, D., M. A. Altabet, D. McCorckle, R. Francois, and G. Fischer (1999), The $\delta 15 \mathrm{~N}$ of nitrate in the Southern Ocean: Consumption of nitrate in surface waters, Global Biogeochem. Cycles, 13, 1149-1166.

Sigman, D. M., J. Granger, P. J. DiFiore, M. M. Lehrmann, R. Ho, G. Cane, and A. van Geen (2005), Coupled nitrogen and oxygen isotope measurements of nitrate along the eastern North Pacific margin, Global Biogeochem. Cycles, 19 , GB4022, doi:10.1029/2005GB002458

Silva, J. A., and J. M. Bremner (1966), Determination and isotope ratio analysis of different forms of nitrogen in soils. 5. Fixed ammonium, Soil Sci. Soc. Am. Proc., 30, 587-594.

Sluijs, A., et al. (2006), Subtropical Arctic Ocean temperatures during the Paleocene/Eocene thermal maximum, Nature, 441, 610-613.

Stein, R. (1986), Surface-water-paleo-productivity as inferred from sediments deposited in oxic and anoxic deep-water environment of the Mesozoic Atlantic Ocean, in Biogeochemistry of Black Shales, edited by E. T. Degens, Mitt. Geol. Palaeontol. Inst. Univ. Hamburg, 60, 55-70.

Stein, R. (1991), Accumulation of Organic Carbon in Marine Sediments, 217 pp., Springer, Berlin.

Stein, R. (2007), Upper Cretaceous/lower Tertiary black shales near the North Pole: Organic-carbon origin and source rock potential, Mar. Pet. Geol., 24, 67-73.

Stein, R., and R. W. Macdonald (2004), The Organic Carbon Cycle in the Arctic Ocean, 363 pp., Springer, Berlin.

Stein, R., B. Boucsein, and H. Meyer (2006), Anoxia and high primary production in the Palaeogene central Arctic Ocean: First detailed records from Lomonosov Ridge, Geophys. Res. Lett., 33, L18606, doi:10.1029 2006GL026776.

Svensen, H., S. Planke, A. Malthe-Sørenssen, B. Jamtveit, R. Myklebust, T. Rasmussen Eidem, and S. S. Rey (2004), Release of methane from a volcanic basin as a mechanism for initial Eocene global warming, Nature, 429 , $542-545$.

Thomas, D. J., T. J. Bralower, and J. C. Zachos (1999), New evidence for subtropical warming 
during the late Paleocene thermal maximum: Stable isotopes from Deep Sea Drilling Project Site 527, Walvis Ridge, Paleoceanography, $14,561-570$.

Thomas, D. J., J. C. Zachos, T. J. Bralower, E. Thomas, and S. Bohaty (2002), Warming the fuel for the fire: Evidence for the thermal dissociation of methane hydrate during the Paleocene-Eocene thermal maximum, Geology, 30, 1067-1070.

Tripati, A. K., and H. Elderfield (2004), Abrupt hydrographic changes in the equatorial Pacific and subtropical Atlantic from foraminiferal $\mathrm{Mg} / \mathrm{Ca}$ indicate greenhouse origin for the thermal maximum at the Paleocene-Eocene boundary, Geochem. Geophys. Geosyst., 5, Q02006, doi:10.1029/2003GC000631.

Tyrrell, T. (1999), The relative influences of nitrogen and phosphorus on oceanic primary production, Nature, 400, 525-531.

Villareal, T. A. (1991), Nitrogen-fixation by the cyanobacterial symbiont of the diatom genus Hemiaulus, Mar. Ecol. Prog. Ser., 76, 201-204.

Vincent, E., and W. H. Berger (1985), Carbon dioxide and polar cooling in Miocene: The Monterey hypothesis, in The Carbon Cycle and Atmospheric $\mathrm{CO}_{2}$ : Natural Variations, Archean to Present, Geophys. Monogr. Ser. vol. 32, edited by E. T. Sundquist and W. S. Broecker, pp. 455-468, AGU, Washington D. C.

Voss, M., K.-C. Emeis, S. Hille, T. Neumann, and J. W. Dippner (2005), Nitrogen cycle of the Baltic Sea from an isotope perspective, Global Biogeochem. Cycles, 19, GB3001, doi:10.1029/2004GB002338.

Walsh, J. J. (1996), Nitrogen fixation within a tropical upwelling ecosystem: Evidence for a Redfield budget of carbon/nitrogen cycling by the total phytoplankton community, J. Geophys. Res., 101, 20,607-20,616.

Westberry, T. K., and D. A. Siegel (2005), Spatial and temporal distribution of Trichodesmium blooms in the world's oceans, Global Biogeochem. Cycles, 20, GB4016, doi:10.1029/ 2005GB002673.

Wheeler, P. A., M. Gosselin, E. Sherr, D. Thibault, D. L. Kirchman, R. Benner, and T. E. Whitledge (1996), Active cycling of organic carbon in the central Arctic Ocean, Nature, 380, 697-699.

White, A. E., F. G. Prahl, R. M. Letelier, and B. N. Popp (2007), Summer surface waters in the Gulf of California: Prime habitat for biological $\mathrm{N}_{2}$ fixation, Global Biogeochem. Cycles, 21, GB2017, doi:10.1029/2006GB002779.

Winkelman, D., and J. Knies (2005), Recent distribution and accumulation of organic carbon on the continental margin west off Spitsbergen, Geochem. Geophys. Geosyst., 6, Q09012, doi:10.1029/2005GC000916.

Zachos, J. C., M. Pagani, L. Sloan, E. Thomas, and K. Billups (2001), Trends, rhythms, and aberrations in global climate 65 Ma to present, Science, 292, 686-693.

Zachos, J. C., M. W. Wara, S. Bohaty, M. L. Delaney, M. R. Petrizzo, T. J. Bralower, and I. Premoli-Silva (2003), A transient rise in tropical sea surface temperature during the Paleocene-Eocene thermal maximum, Science, 302, 1551-1554.

Zachos, J. C., S. Schouten, S. Bohaty, T. Quattlebaum, A. Sluijs, H. Brinkhuis, S. J. Gibbs, and T. J. Bralower (2006), Extreme warming of mid-latitude coastal ocean during the Paleocene-Eocene thermal maximum: Inferences from $\mathrm{TEX}_{86}$ and isotope data, Geology, 34, 737-740.

H.-J. Brumsack, Institute for Chemistry and Biology of the Marine Environment, Oldenburg University, D-26111 Oldenburg, Germany. (brumsack@icbm.de)

J. Knies, Geological Survey of Norway, NO7491 Trondheim, Norway. (jochen.knies@ngu no)

U. Mann, SINTEF Petroleum Research, NO7465 Trondheim, Norway. (ute.mann@iku.sintef no)

B. N. Popp, Department of Geology and Geophysics, University of Hawai'i at Manoa, Honolulu, Hawaii, 96822 USA. (popp@hawaii. edu)

R. Stein, Alfred Wegener Institute for Polar and Marine Research, D-27568 Bremerhaven, Germany. (ruediger.stein@awi.de) 